\title{
A prospective study on pregnancy complicated with jaundice with special emphasis on fetomaternal outcome
}

\section{Neha Choudhary*, Sangeeta Sen, Varalakshmi K.}

Department of Obstetrics and Gynecology, Panna Dhaya Zanana Hospital, RNT Medical College, Udaipur, Rajasthan, India

Received: 13 September 2017

Accepted: 06 October 2017

*Correspondence:

Dr. Neha Choudhary,

E-mail: nehachoudhary1710@gmail.com

Copyright: (c) the author(s), publisher and licensee Medip Academy. This is an open-access article distributed under the terms of the Creative Commons Attribution Non-Commercial License, which permits unrestricted non-commercial use, distribution, and reproduction in any medium, provided the original work is properly cited.

\begin{abstract}
Background: Jaundice defined as yellow discolouration of skin, sclera and mucus membrane resulting from increased serum bilirubin concentration. It is usually clinical visible when plasma bilirubin exceeds $3 \mathrm{mg} / \mathrm{dl}$. This study aimed at determining maternal and foetal outcome in women with jaundice complicating pregnancy.

Methods: This prospective study was conducted on 58 cases of pregnant women with jaundice (serum bilirubin $\geq 3$ mg\%) admitted at Panna Dhaya Zanana Hospital (PDZH), RNT Medical College, Udaipur, Rajasthan from January 2016 December 2016.

Results: The incidence observed in this study was $0.28 \% .77 .59 \%$ cases in this study were in third trimester of pregnancy. Serum bilirubin was $>20 \mathrm{mg} \%$ in $5.18 \%$ cases. Haemolysis, elevated liver enzymes, low platelets (HELLP) syndrome, acute fatty liver of pregnancy, intrahepatic cholestasis of pregnancy, viral hepatitis and malaria were the causes of jaundice. HELLP syndrome was the most common cause of jaundice. Of 58 women 38 delivered vaginally and 12 were LSCS for obstetrical indication and 8 were undelivered. The disease is associated with high incidence of preterm labour, IUGR, birth asphyxia and foetal distress. Perinatal mortality was 38\%. Maternal mortality in 11 cases i.e. 18.96\%. Main causes of maternal mortality were hepatic encephalopathy, DIC followed by shock due to PPH, DIC followed by multiple organ dysfunction syndrome.

Conclusion: Jaundice and pregnancy having a grave prognosis, resulting in a very high perinatal as well as maternal morbidity and mortality, and requires an early diagnosis and careful management.
\end{abstract}

Keywords: Jaundice, Pregnancy with jaundice, Serum bilirubin

\section{INTRODUCTION}

Jaundice is defined as yellow discoloration of skin, sclera and mucous membrane resulting from increased serum bilirubin concentration. It is usually clinically visible when plasma bilirubin exceeds $3 \mathrm{mg} / \mathrm{dl}{ }^{1}$

The normal physiological changes in pregnancy e.g. palmar erythema, spider naevus, cherry angiomata, lithogenic bile, cholestasis etc. may mimic liver disease, but can be attributed to increase serum estrogen and progesterone. $^{2}$
Physiological changes during pregnancy leads to increase in alkaline phosphatase levels 3 to 4-fold and no change in liver transaminase levels (AST, ALT), GGT, Bilirubin level, prothrombin time, blood flow to the liver. ${ }^{3}$

Pregnancy with jaundice is considered as high-risk pregnancy carrying grave prognosis for both mother and foetus. Up to $3 \%$ of all pregnancies are complicated by liver disorders. ${ }^{4}$ Incidence of jaundice in pregnancy is $0.4-0.9 / 1000$ in India. Jaundice in pregnancy carries adverse fetomaternal outcome and accounts for $60 \%$ of perinatal and $14 \%$ of maternal mortality. ${ }^{5}$ 
Table 1: Clinical features of the most common liver disease that occurs in pregnancy.

\begin{tabular}{|c|c|c|c|c|c|c|}
\hline Condition & $\begin{array}{l}\text { Main } \\
\text { symptoms }\end{array}$ & Trimester & bilirubin & Transaminases & $\begin{array}{l}\text { Platelet } \\
\text { count }\end{array}$ & $\begin{array}{l}\text { Other } \\
\text { features }\end{array}$ \\
\hline $\begin{array}{l}\text { Hyperemesis } \\
\text { gravidarum }(\mathrm{HG})\end{array}$ & $\begin{array}{l}\text { Prolong } \\
\text { nausea, } \\
\text { vomiting, } \\
\text { weight loss } \\
\text { and nutritional } \\
\text { deficiency }\end{array}$ & $\begin{array}{l}1 \mathrm{st} \\
\text { trimester }\end{array}$ & $\uparrow$ & $\begin{array}{l}\text { Normal to mild } \\
\text { rise upto } \leq 250 \\
\text { IU/L }\end{array}$ & $\begin{array}{l}\text { Normal } \\
\text { levels }\end{array}$ & Ketonuria \\
\hline $\begin{array}{l}\text { Intrahepatic } \\
\text { cholestasis of } \\
\text { pregnancy (ICP) }\end{array}$ & $\begin{array}{l}\text { Pruritus, } \\
\text { steatorrhea, } \\
\text { abdominal } \\
\text { pain }\end{array}$ & $\begin{array}{l}2^{\text {nd }}-3^{\text {rd }} \\
\text { trimester }\end{array}$ & $\uparrow \uparrow \uparrow$ & $\begin{array}{l}\text { Normal to mild } \\
\text { rise upto } \\
\leq 250 \mathrm{IU} / \mathrm{L}\end{array}$ & $\begin{array}{l}\text { Normal } \\
\text { levels }\end{array}$ & Bilirubinuria \\
\hline $\begin{array}{l}\text { Acute fatty liver of } \\
\text { pregnancy(AFLP) }\end{array}$ & $\begin{array}{l}\text { Epigastric } \\
\text { /right upper } \\
\text { quadrant pain, } \\
\text { nausea, } \\
\text { vomiting, } \\
\text { malaise, } \\
\text { fatigue }\end{array}$ & $\begin{array}{l}3^{\text {rd }} \\
\text { trimester }\end{array}$ & $\uparrow$ & Markedly high & $\begin{array}{l}\text { Normal } \\
\text { levels }\end{array}$ & $\begin{array}{l}\text { Associated with } \\
\text { pre-eclampsia in } \\
\text { about } 50 \%\end{array}$ \\
\hline $\begin{array}{l}\text { Pre- } \\
\text { eclampsia/eclampsia }\end{array}$ & $\begin{array}{l}\text { Hypertension, } \\
\text { edema, } \\
\text { epigastric } \\
\text { /right upper } \\
\text { quadrant pain, } \\
\text { neurological } \\
\text { deficit } \\
\text { (headache, } \\
\text { seizures, } \\
\text { blurring of } \\
\text { vision, coma) }\end{array}$ & $\begin{array}{l}2^{\text {nd }}-3^{\text {rd }} \\
\text { trimester } \\
\text { and } \\
\text { postpartum }\end{array}$ & $\uparrow$ & Markedly High & $\begin{array}{l}\text { Normal } \\
\text { levels or } \\
\downarrow\end{array}$ & $\begin{array}{l}\text { High uric acid } \\
\text { levels,proteinuria }\end{array}$ \\
\hline $\begin{array}{l}\text { Syndrome of } \\
\text { haemolysis, elevated } \\
\text { liver enzymes and } \\
\text { low platelets } \\
\text { (HELLP) }\end{array}$ & $\begin{array}{l}\text { Hypertension, } \\
\text { edema, } \\
\text { epigastric } \\
\text { /right upper } \\
\text { quadrant pain, } \\
\text { neurological } \\
\text { deficit } \\
\text { (headache, } \\
\text { seizures, } \\
\text { blurring of } \\
\text { vision, coma) }\end{array}$ & $\begin{array}{l}2^{\text {nd }}-3^{\text {rd }} \\
\text { trimester } \\
\text { and } \\
\text { postpartum }\end{array}$ & $\uparrow$ & Markedly high & $\begin{array}{l}\text { Low } \\
\text { levels }\end{array}$ & $\begin{array}{l}\text { Haemolysis, } \\
\text { high uric acid } \\
\text { levels, } \\
\text { proteinuria }\end{array}$ \\
\hline
\end{tabular}

Liver disorders in pregnancy is multifactorial in origin. Jaundice in pregnancy can be classified in 3 categories:

- Jaundice specific to pregnancy such as Hyperemesis gravidarum, intrahepatic cholestasis of pregnancy, acute fatty liver of pregnancy, preeclampsia/ eclampsia, and HELLP syndrome. These occur in patients with previously healthy liver and usually resolve spontaneously in puerperium

- Pregnancy in preexisting chronic liver disease, e.g. cirrhosis of liver, chronic viral hepatitis, Wilson's disease
- Pregnancy with acute viral hepatitis which may lead to fulminant hepatic failure, e.g. hepatitis E, hepatitis $\mathrm{B}$, hepatitis A, HSV etc. and drug induced hepatitis.

Viral hepatitis is the most common cause of jaundice in pregnancy. ${ }^{6,7} \mathrm{HEV}$ and $\mathrm{HBV}$ were most frequent cause of fulminant hepatic failure in pregnancy. ${ }^{1,8,9}$ In developing countries as India, Hepatitis E is the most common cause of fulminant hepatic failure. ${ }^{10-12}$ In viral hepatitis patient presents with prodromal symptoms like vomiting, fatigue, malaise, arthralgia, myalgia and headache. Liver becomes enlarged and tender leading to abdominal pain. ${ }^{2}$ Intrahepatic cholestasis is found to be the second most common cause of jaundice in pregnancy. ${ }^{6}$ 
In the present study, aim is to determine the fetomaternal outcome in pregnancy complicated by jaundice at Panna Dhay Zanana hospital, Udaipur. This includes:

- Incidence of jaundice in pregnancy in Panna Dhay Zanana Hospital, Udaipur.

- Etiological factors for jaundice in pregnancy.

- Clinical presentations in pregnant women with jaundice.

- Maternal and fetal morbidity and mortality in pregnancies complicated with jaundice.

\section{METHODS}

Present study was a prospective study. The study was conducted on 58 cases of pregnant women with jaundice (serum bilirubin $\geq 3 \mathrm{mg} \%$ ) admitted at Panna Dhay Zanana Hospital (PDZH), RNT Medical College, Udaipur, Rajasthan from January 2016 December 2016.

The diagnosis of each case of jaundice in pregnant women was based on clinical evaluation, biochemical and hematological parameters and in all cases foetomaternal outcome analysed in detail as follows:

\section{History}

A detailed history of present illness including origin, duration and progress of following symptoms like yellow colored urine, anorexia, nausea, vomiting, fever, epigastric pain and pain in abdomen, constipation/diarrhea, irritability and weakness.

\section{General physical examination}

A thorough general examination was carried out with special attention to:

- The evidence if yellow discoloration of sclera, skin and mucus membrane and yellow urine

- Level of consciousness

- Built and nutrition

- Pulse, temperature, respiration and blood pressure

- Presence of anemia and fever

- Edema of face, feet, abdomen wall, vulva and may involve whole body

- Enlargement of lymph nodes.

\section{Systemic examination}

Abdomen was examined for any lump including liver and spleen. Ascites and tender areas were looked for.

A thorough obstetrical examination in each case was carried out in detail. It included

- Per abdomen examination in each and every case

- Per speculum and per vaginal examination whenever it was necessary.

\section{Investigations}

Every patient was investigated as follows.

- Routine examination for $\mathrm{CBC}$ and $\mathrm{PBF}$ for hemoglobin, total and differential white cell count, platelet counts, blood group, TSH, blood sugar, blood urea, HIV, VDRL, malaria.

- Urine examination was carried out for presence of albumin, sugar, bile salts, bile pigments, urobilinogen and microscopical abnormalities.

- Liver function tests included-

a) Serum bilirubin

b) Plasma proteins

c) Serum transaminases enzymes (SGOT, SGPT) exceed more than 400IU/L indicates liver injury.

d) Alkaline phosphatase (ALP)

e) Gamma glutamyl transferase

f) Coagulation profile including bleeding time, clotting time and prothrombin time (BT, CT, PT/INR).

- $\quad$ Serological tests for viral markers

a) IgM anti-HAV antibody

b) $\mathrm{HBV}$ (HBsAg, HBeAg, IgM anti $\mathrm{HBV}$ core antigen)

c) IgM anti-HCV antibody

d) IgM anti-HEV antibody

e) Herpes simplex virus PCR.

\section{RESULTS}

The incidence observed in this study is 2.8 pregnant women with jaundice/1000 pregnancies $(0.28 \%)$ recorded at Panna Dhai Zanana Hospital, Udaipur (Rajasthan, India) in the duration from January 2016 to December 2016 (Table 2).

Table 2: Incidence of pregnancy complicated with jaundice.

\begin{tabular}{|llllll|}
\hline Period of study & $\begin{array}{l}\text { Total no. of } \\
\text { deliveries }\end{array}$ & $\begin{array}{l}\text { Total no. of } \\
\text { abortion }\end{array}$ & $\begin{array}{l}\text { Total no. of } \\
\text { pregnancies }\end{array}$ & $\begin{array}{l}\text { Total no. of cases of } \\
\text { jaundice with pregnancy }\end{array}$ & Incidence (\%) \\
\hline $\begin{array}{l}\text { January 2016 to } \\
\text { December 2016 }\end{array}$ & 19494 & 1288 & 20782 & 58 & $0.28 \%$ \\
\hline
\end{tabular}


Of those 58 women, $68.97 \%(40 / 58)$ were unbooked and $72.42 \%(42 / 58)$ were from rural area. The incidence of jaundice in pregnancy were highest in primigravida i.e. $50 \%$. In this study the disease was found to be more common in younger age group, highest $(56.89 \%)$ in the age group of 21-29 years. It may be due to the fact that higher no. of pregnancies was in this age group. Most of cases were in $3^{\text {rd }}$ trimester that is $77.59 \%$ followed by $2^{\text {nd }}$ trimester and least no. of cases presented in $1^{\text {st }}$ trimester.

Clinical picture of pregnant women with jaundice was extremely variable from the stage of slight malaise in early stage which can be neglected easily by many to a very severe form culminating into hepatic coma and eventual death.

In all patients more than one symptom was present. Chief symptoms that were observed are nausea, vomiting, loss of appetite, epigastric pain and dark or yellow colored urine.

In this study most common presenting symptom were nausea and vomiting that were $56.90 \%$ and $44.83 \%$ followed by Loss of appetite and yellow colored urine were as presenting feature in $41.38 \%$. Epigastric pain or pain in right hypochondrium was presenting symptoms in $34.48 \%$. Pruritus is presenting symptom in $13.79 \%$ cases of jaundice in pregnancy. Only one patient had complaint of hematemesis. All 58 patients i.e. $100 \%$ had icterus at the time of admission (Table 3 ).

Table 3: Clinical findings observed in this study.

\begin{tabular}{|c|c|c|}
\hline Symptoms & $\begin{array}{l}\text { No. of } \\
\text { patients }\end{array}$ & Percentage \\
\hline Icterus & 58 & 100 \\
\hline Yellow/dark colored urine & 53 & 91.38 \\
\hline Fever & 33 & 56.90 \\
\hline Pallor & 31 & 53.45 \\
\hline Nausea & 33 & 56.90 \\
\hline Vomiting & 26 & 44.83 \\
\hline Edema & 27 & 46.55 \\
\hline Loss of appetite & 24 & 41.38 \\
\hline Yellow/dark colored urine & 24 & 41.38 \\
\hline $\begin{array}{l}\text { Epigastric pain/pain in } \\
\text { abdomen }\end{array}$ & 20 & 34.48 \\
\hline $\begin{array}{l}\text { Tenderness in right } \\
\text { hypochondrium/ epigastric } \\
\text { region }\end{array}$ & 13 & 22.41 \\
\hline Unconsciousness /coma & 11 & 18.96 \\
\hline Hepatomegaly & 11 & 18.96 \\
\hline Itching (pruritus) & 8 & 13.79 \\
\hline
\end{tabular}

$53.45 \%$ of cases showed positive for bile pigments and bile salts in urine. 27 (46.55\%) cases showed positive for protein in their urine.
Serum bilirubin level varied widely between $3 \mathrm{mg} \%$ to $24.15 \mathrm{mg} \%$ in group.

The serum transaminase level was raised in majority of cases of jaundice in pregnancy. Serum alkaline phosphatase was $\leq 400 \mathrm{IU} / \mathrm{L}$ in $68.97 \%$ cases and $\geq 800$ IU/L in $12.07 \%$ cases. Raised serum transaminases are due to hepatocellular injury and raised alkaline phosphatase reflects degree of cholestasis in cases of jaundice (Table 4).

Table 4: Distribution according to liver enzymes serum transaminase level and serum alkaline phosphatase.

\begin{tabular}{|lcl|}
\hline SGOT (IU/L) & No. of patient & Percentage \\
\hline$\leq 200$ & 37 & 63.79 \\
\hline $200-500$ & 17 & 29.31 \\
\hline$\geq 500$ & 4 & 6.90 \\
\hline SGPT (IU/L) & & \\
\hline$\leq 200$ & 35 & 60.34 \\
\hline $200-500$ & 17 & 29.31 \\
\hline$\geq 500$ & 6 & 10.35 \\
\hline Alkaline phosphatase & $(\mathbf{U} / \mathbf{L})$ & \\
\hline$\leq 400$ & 40 & 68.97 \\
\hline $400-800$ & 11 & 18.96 \\
\hline$\geq 800$ & 7 & 12.07 \\
\hline
\end{tabular}

Coagulation parameters found altered in 21 patients. Out of which 13 patients went into DIC (Table 5). Among 58 cases 15 patients $(25.86 \%)$ received blood transfusion of various component to maintain their vitals haemodynamically stable. Two patients with HELLP syndrome with DIC transfused 8 Packed cells, 12 FFP and 12 platelets.

Table 5: Coagulation parameters.

\begin{tabular}{|llll|}
\hline \multirow{2}{*}{ Test } & Level & $\begin{array}{l}\text { No. of } \\
\text { patients } \\
(\mathbf{n = 5 8 )}\end{array}$ & Percentage \\
\hline \multirow{2}{*}{ PT/INR } & Normal & 37 & 63.79 \\
\hline FDP (Fibrin & Raised & 21 & 36.20 \\
\hline degradation product) & Normal & 47 & 81.04 \\
\cline { 2 - 4 } D-dimer & Raised & 11 & 18.96 \\
\hline & Normal & 49 & 84.48 \\
\hline & Raised & 9 & 15.52 \\
\hline
\end{tabular}

In present study most common predominant cause of jaundice in pregnant women was pre-eclampsia, HELLP syndrome that was observed in $27(46.55 \%)$ cases.

$2^{\text {nd }}$ most common cause was viral hepatitis found in 11 $(18.96 \%)$ cases followed by intrahepatic cholestasis of pregnancy that was found in $9(15.52 \%)$ cases. Majority of cases of HELLP syndrome i.e.50\% were in Mississippi Class 3 (Figure 1). 


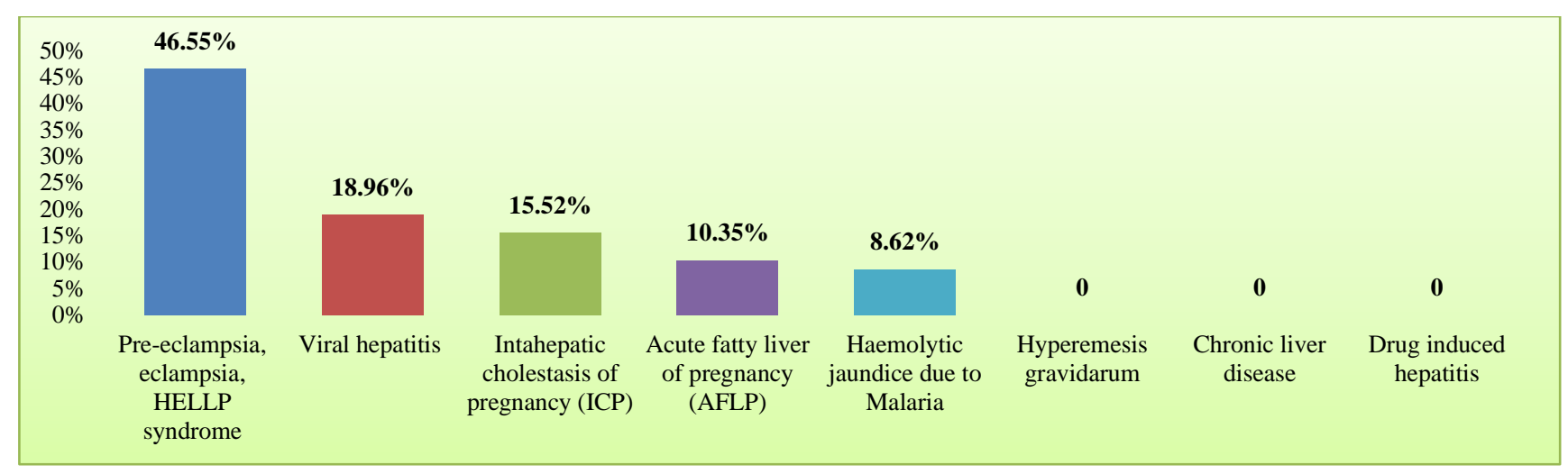

Figure 1: Distribution of cases according to etiological factors of jaundice in pregnant women.

Table 6: Obstetrical outcome.

\begin{tabular}{|lll|}
\hline Outcome & No. of patient & Percentage \\
\hline Mode of delivery & 37 & $63.79 \%$ \\
\hline $\begin{array}{l}\text { Vaginal } \\
\text { Instrumental vaginal } \\
\text { (forceps, ventouse) }\end{array}$ & 1 & $1.72 \%$ \\
\hline Caesarean section & 12 & $20.67 \%$ \\
\hline Undelivered & 8 & $13.79 \%$ \\
\hline Improved and discharged & 3 & $5.18 \%$ \\
\hline $\begin{array}{l}\text { Left against medical } \\
\text { advice }\end{array}$ & 1 & $1.72 \%$ \\
\hline Expired undelivered & 2 & $3.45 \%$ \\
\hline Aborted & 2 & $3.45 \%$ \\
\hline
\end{tabular}

\section{Obstetrical outcome}

In this study out of total 58 pregnant women 50 patients delivered. Among 8 undelivered patients 2 were early pregnancy aborted, 3 patient improved condition and discharged, one patient left against medical advice and 2 patients expired undelivered (Table 6). The obstetrical outcome in delivered patients in terms of mode of delivery is shown in Table 6.

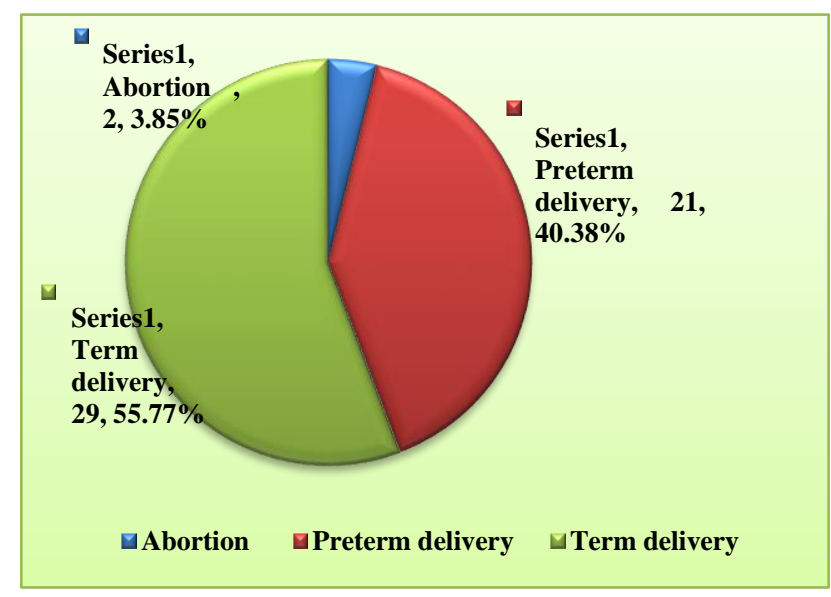

Figure 2: Pregnancy outcome of women who delivered $(n=52)$.
In this study $55.77 \%$ had term delivery, $40.38 \%$ had preterm delivery and $3.85 \%$ cases aborted among 52 patients. Among 21 cases of preterm delivery $66.67 \%$ were spontaneously occurred and rest of $33.33 \%$ were iatrogenically induced as when the risk of continuation of pregnancy was more for mother (Figure 2).

\section{Table 7: Maternal morbidity and mortality.}

\begin{tabular}{|l|l|l|}
\hline Maternal complication & No. of patients & Percentage \\
\hline Postpartum haemorrhage & 21 & 36.21 \\
\hline DIC & 13 & 22.41 \\
\hline Renal failure & 13 & 22.41 \\
\hline Hepatic encephalopathy & 12 & 20.67 \\
\hline Eclampsia & 10 & 17.24 \\
\hline Abruptio placentae & 6 & 10.35 \\
\hline Septicaemia & 3 & 5.18 \\
\hline Oesophageal varices & 1 & 1.72 \\
\hline Coma & 9 & 15.52 \\
\hline Death & 11 & 18.96 \\
\hline
\end{tabular}

In present study most common maternal complication was atonic PPH which occurred in $36.21 \%$ cases followed by DIC and renal failure each in $22.41 \%$ cases. Hepatic encephalopathy found in 12 (20.67\%) cases among them $9(15.52 \%)$ cases had coma. Only one patient had oesophageal varices at time of hospital admission (Table 7).

Table 8: Causes of maternal mortality.

\begin{tabular}{|lll|}
\hline Cause of mortality & $\begin{array}{l}\text { No. of } \\
\text { patients } \\
(\mathbf{n = 1 1 )}\end{array}$ & Percentage \\
\hline $\begin{array}{l}\text { Multiple organ dysfunction } \\
\text { syndrome }\end{array}$ & 4 & 36.36 \\
\hline $\begin{array}{l}\text { HELLP Syndrome with DIC } \\
\text { with acute renal failure }\end{array}$ & 2 & 18.18 \\
\hline Hepatic encephalopathy & 2 & 18.18 \\
\hline $\begin{array}{l}\text { Cerebral malaria } \\
\text { Septicaemia }\end{array}$ & 2 & 18.18 \\
\hline
\end{tabular}


In present study maternal mortality was $18.96 \%$. in majority of cases cause of mortality was multiple organ dysfunction syndrome (MODS) accounting for $36.36 \%$ of all mortality followed by HELLP syndrome with DIC with acute renal failure, hepatic encephalopathy and cerebral malaria each for $18.18 \%$. One case $(9.09 \%)$ died as a result of septicaemia (Table 8).

\section{Perinatal outcome}

Among 50 deliveries still birth was $30 \%$, early neonatal death was $8 \%$ and baby discharged healthy were $62 \%$. Perinatal mortality in this study was $38 \%$.

Most common cause of neonatal mortality in present study was prematurity and low birth weight in $42.11 \%$ followed by birth asphyxia and foetal distress (Figure 3 ).

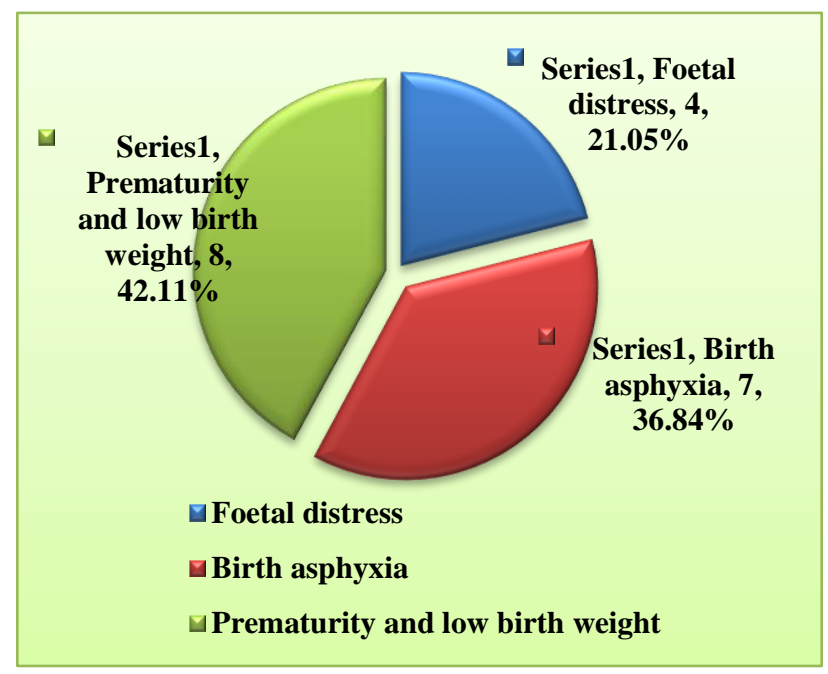

Figure 3: Causes of perinatal mortality $(n=19)$.

In the present study $31.43 \%$ out of 35 live born babies required NICU admission, leading cause was prematurity and low birth weight i.e.45.45\% followed by birth asphyxia i.e. $27.27 \%$, meconium aspiration syndrome i.e. $18.28 \%$ and sepsis i.e. $9.09 \%$.

\section{DISCUSSION}

The incidence of jaundice in India varies from 0.4 to $0.9 / 1000$ deliveries. Present incidence is $0.28 \%$ deliveries. Krishnamoorthy $\mathrm{J}$ et al reported $0.29 \%$ incidence while Acharya $\mathrm{N}$ et al and Karegoudar D et al reported $0.4 \%$ incidence. In the present study, most of the women $28(75.68 \%)$ belonged to age group of 21 to 30 years. $^{6,12,13}$

HELLP is commonly encountered in the second or third trimester but can also arise after delivery. ${ }^{14}$ In the present study, the predominant cause of jaundice was found to be of pre-eclampsia, HELLP syndrome that was observed in $27(46.55 \%)$ cases. $2^{\text {nd }}$ most common cause was viral hepatitis found in $11(18.96 \%)$ cases followed by intrahepatic cholestasis of pregnancy that was found in 9 $(15.52 \%)$ cases.

Comparable results cited by Reddy MG et al who noted hemolysis, elevated liver enzymes, low platelets (HELLP) syndrome, acute fatty liver of pregnancy, intrahepatic cholestasis of pregnancy, viral hepatitis, malaria and sickle cell anemia were the causes of jaundice in their study. HELLP syndrome (33.3\%) was the most common cause of jaundice followed by AFLP in $22.2 \%$ cases and Karegoudar D. et al observed that among 37 pregnant women with jaundice predominant cause of jaundice was HELLP 24 (64.86\%) followed by acute viral hepatitis and Leptospirosis 5 (13.51\%) of each. ${ }^{1,12}$

HEV infection is the most prevalent and dangerous type of viral hepatitis in Asian and African continents. The incidence reported by a study done by ICMR is as high as $80-90 \%$ in cases of viral hepatitis in pregnancies. In present study Hep E virus found to be most common cause of viral hepatitis it accounts for $45.45 \%$ of cases of viral hepatitis. Other studies reported as Acharya $\mathrm{N}$ et al, Ambreen $\mathrm{A}$ et al and Parveen $\mathrm{T}$ et al noted HEV being the commonest with a high maternal and perinatal mortality. ${ }^{6,8,9}$ Reyes $\mathrm{H}$ and Simms HF et al studied the course of viral hepatitis in pregnancy and concluded that its course is unaltered in pregnancy, except in cases of HEV infected cases, in which cases hepatitis has more fulminant course. ${ }^{15,16}$

However, Sharma S et al found Hepatitis B was the most common cause of acute hepatitis $(26.7 \%)$ and incidence of hepatitis E was $13.3 \%$ in this study. ${ }^{17}$

Acute fatty liver during pregnancy usually occurs in the $3^{\text {rd }}$ trimester. Preeclampsia is associated in $50-100 \%$ of cases. There is moderately increased liver enzyme level of $<1000 \mathrm{IU} / \mathrm{mL}$, bilirubin level of $1-10 \mathrm{mg} \%$ and hypoglycemia. The maternal mortality is $18 \%$ while preterm labor is increased and the perinatal mortality is $23 \% .{ }^{18}$ In our observations AFLP was found as cause of jaundice in $6(10.35 \%)$ cases, half of AFLP patients had preeclampsia.

Jaundice in pregnancy is associated with high maternal and perinatal mortality rates. We observed in this study that out of 50 delivered cases $62 \%$ babies were alive, $30 \%$ stillbirth and early neonatal death in $8 \%$ cases. Perinatal mortality in this study was $38 \%$. Prematurity and low birth weight in $42.11 \%$ accounted for majority of the deaths. Higher perinatal mortality was also supported by these studies as Tripti $\mathrm{N}$ et al reported that perinatal mortality was $61.76 \%$ with $50 \%$ stillbirth and $11.76 \%$ early neonatal death. ${ }^{5}$

Perinatal mortality was observed as cited by Acharya $\mathrm{N}$ et al $16.6 \%$, Karegoudar D et al $46.16 \%$, Jayanti $\mathrm{N}$ et al $19 \%$ and Mitta $\mathrm{P}$ et al $30.76 \%{ }^{6,12,19,20}$ In the present study $31.43 \%$ out of 35 live born babies required NICU 
admission, most common indication for NICU admission was prematurity and low birth weight that was in $45.45 \%$ of total NICU admissions. This was followed by birth asphyxia, meconium aspiration syndrome and sepsis.

Jaundice in pregnancy accounted for maternal mortality $18.96 \%$ that occurred in our department during the period of study. In majority of cases cause of mortality was multiple organ dysfunction syndrome (MODS) accounting for $36.36 \%$ of all mortality followed by HELLP syndrome with DIC with acute renal failure, hepatic encephalopathy and cerebral malaria each for $18.18 \%$. One case $(9.09 \%)$ died as a result of septicemia.

Various studies also report jaundice as one of the major indirect cause of maternal death. Similarly high maternal mortality observed by other studies. Tripti $\mathrm{N}$ et al noted maternal mortality was $24.4 \%$. Cause of death was hepatic encephalopathy with renal failure in $60 \%$, disseminated intravascular coagulation in $20 \%$, postpartum hemorrhage and congestive cardiac failure associated with severe anemia in $10 \%$ each. $^{5}$

Karegoudar D et al noted maternal mortality was $75.68 \% .^{12}$ Reddy MG et al noted among 18 cases of jaundice in pregnancy maternal mortality in $3(16.66 \%)$ cases. ${ }^{1}$

Maternal mortality in other studies also comparable as Jayanti $\mathrm{N}$ et al $10 \%$, Wani $\mathrm{S}$ et al noted $11 \%$ and Krishnamoorthy $\mathrm{J}$ et al noted $7.8 \%$. Sharma $\mathrm{S}$ et al reported that maternal mortality was found in 1 out of 30 cases i.e. $3.33 \%$ due to hepatic encephalopathy and coagulopathy. ${ }^{10,13,17,19}$

Maternal deaths were directly proportional to the level of the serum bilirubin. Tripti $\mathrm{N}$ et al and Trivedi et al also observed the same. ${ }^{5}$

\section{CONCLUSION}

By the present study we concluded that pregnancy complicated with jaundice have very poor maternal as well as foetal outcome. In this study most common predominant cause was pre-eclampsia, HELLP syndrome followed by viral hepatitis. However, the prevalence and aetiology of jaundice still remain debatable in developing and developed countries.

We observed maternal mortality was $18.96 \%$ and perinatal mortality was $38 \%$ this shows grave feto maternal prognosis for pregnancy complicated with jaundice.

Poor fetomaternal outcome associated with poor nutrition, prevalence of anaemia, delay in seeking medical advice and delay in referral to the hospital. Many of the patients when brought to the hospital are already in moribund condition and often, do not respond to treatment. So health awareness, routine antenatal check- ups and most important is early diagnosis and management is necessary to overcome burden of disease and to reduce high maternal and maternal mortality in jaundiced pregnant women.

\section{ACKNOWLEDGMENTS}

The authors wish to thank all patients for their participation in this study, and all personnel at the Obstetrics and Gynecology Department for their enthusiastic contribution.

Funding: No funding sources

Conflict of interest: None declared

Ethical approval: The study was approved by the Institutional Ethics Committee

\section{REFERENCES}

1. Reddy MG, Prabhakar GC, Sree V. Maternal and fetal outcome in jaundice complicating pregnancy. J NTR Univ Health Sci. 2014;3:231-3.

2. Misra R. Ian Donald's Practical Obstetric Problems, 7th edition. Lippincott Williams and Wilkins; 2014.

3. Mitra AK, Patki PS, Mitra SK. Liver disorders during pregnancy and their management. The Antiseptic. 2008;105(4):193-6.

4. Ch'ng CI, Morgan M, Hainsworth I. Prospective study of liver dysfunction in pregnancy in South West Wales. Gut. 2002;51(6):876-80.

5. Nagaria T, Agarwal S. Fetomaternal outcome in jaundice during pregnancy. J Obstet Gynecol India. 2005;55(5):424-7.

6. Acharya N, Acharya S, Shukla S, Athvale R, Shaveta. Study of jaundice in pregnancy. Global $\mathbf{J}$ Med Res Gynecol Obstet. 2013;13(2).

7. ACOG technical bulletin. Hepatitis in pregnancy. Int J OB-GY. 1993;42:189.

8. Ambreen A, Ahmed F, Sheikh A, Ayub MR, Faryad $\mathrm{N}$, Mushtaq S. Jaundice in pregnancy: a clinical study at Fatima Memorial System. J South Asian Feder Obst Gynae. 2015;7(1):22-5.

9. Parveen T, Begum F, Akhter N. Feto-maternal outcome of jaundice in pregnancy in a tertiary care hospital. Mymensingh Med J. 2015;24(3):528-36.

10. Wani S, Kadri SM, Bhat S. Prevalence of acute viral hepatitis in women presenting with jaundice with fetomaternal outcome. Global J Med Pub Health. $2013 ; 2(6): 1-5$.

11. Krawczynski K, Aggarwal P, Kamili S. Hepatitis E. Infec Dis Clin North Am. 2000:14(3):669-87.

12. Karegoudar D, Patel R, Dhital M, Amgain K. A study of liver disorder and its consequences in 999 pregnant women with jaundice in tertiary care center in Belgaum, Karnataka, India. IOSR J Den Med Sci. 2014;13(5):14-8.

13. Krishnamoorthy J, Murugesan A. Jaundice during pregnancy: maternal and fetal outcome. Int J Reprod Contracept Obstet Gynecol. 2016;5(8):2541-5. 
14. ACG clinical guideline: liver disease and pregnancy. Am J Gastroenterol. 2016;111(2):176.

15. Reyes H, Simon. Intrahapatic cholestasis in pregnancy, an estrogen related disease. Semin Liver Dis. 1993;13:289.

16. Simms HF, Duff P. Viral hepatitis in pregnancy Semin Perinatol. 1993;17:384.

17. Sharma S, Aherwar R, Jawade S. Maternal and fetal outcome in jaundice complicating pregnancy: a prospective study. Int $\mathbf{J}$ Reprod Contracept Obstet Gynecol. 2016;5(4):1084-7.

18. Bera SK, Sen Gupta A. A 12 years study of maternal deaths in Eden hospital. J Obstet Gynecol India 1992;42:182-8.
19. Jayanti N, Bajpayi G, Sharma R. A clinical study on jaundice in pregnancy with special emphasis on fetomaternal outcome. IOSR J Dent Med Sci. 2015;14(3):116-9.

20. Mitta P, Rao SV. Fetomaternal outcome in jaundice complicating pregnancy. IOSR J Dent Med Sci. (IOSR-JDMS). 2016;15(10)(VI):72-6.

Cite this article as: Choudhary N, Sen S, Varalakshmi K. A prospective study on pregnancy complicated with jaundice with special emphasis on fetomaternal outcome. Int J Reprod Contracept Obstet Gynecol 2017;6:5081-8. 